Mr. sc. Sait Š. ŠABOTIĆ

Filozofski fakultet Nikšić

E-mail: sabos@t-com.me

Stručni rad/Professional article

UDK/UDC: 94:314.1(497.16 Bihor i Trgovište)"1830/1831"

Adrović A. (049.3)

DOI: https://doi.org/10.52259/historijskipogledi.2021.4.5.324

\title{
NOVI IZVOR I PODSTREK ZA DALJA PROUČAVANJA - Admir Adrović, STANOVNIŠTVO KADILUKA BIHOR I TRGOVIŠTE U OSMANSKIM POPISIMA IZ 1830/31. GODINE (muslimanski i romski mješoviti defter), Podgorica 2020, 361 str.
}

Osmanistika i uopšte islamistika, još uvijek nemaju onaj značaj koji bi trebalo da imaju u crnogorskoj istoriografiji s obzirom na dugo prisustvo Osmanske države i islama na crnogorskom prostoru. Ti nedostaci nadomještaju se tek u poslednje vrijeme $\mathrm{u}$ kome se bilježi nešto značajniji zamah u izdavačkoj djelatnosti u čijim okriljima se pojavljuju posebna izdanja koja se bave pitanjima iz osmanskog perioda. Potvrđuje to i najnoviji poduhvat mladog istoričara iz Podgorice, Admira Adrovića. On je studije istorije završio na Filozofskom fakultetu u Nikšiću, a postdiplomske studije $u$ Istanbulu, na Istanbul Univerzitetu, pod mentorstvom poznatog profesora İdrisa Bostana. Tokom studija i boravka u Istanbulu, Adrović je savladao savremeni turski, ali i osmanski jezik. Ta dragocjena znanja uveliko su mu pomogla da izvrši i

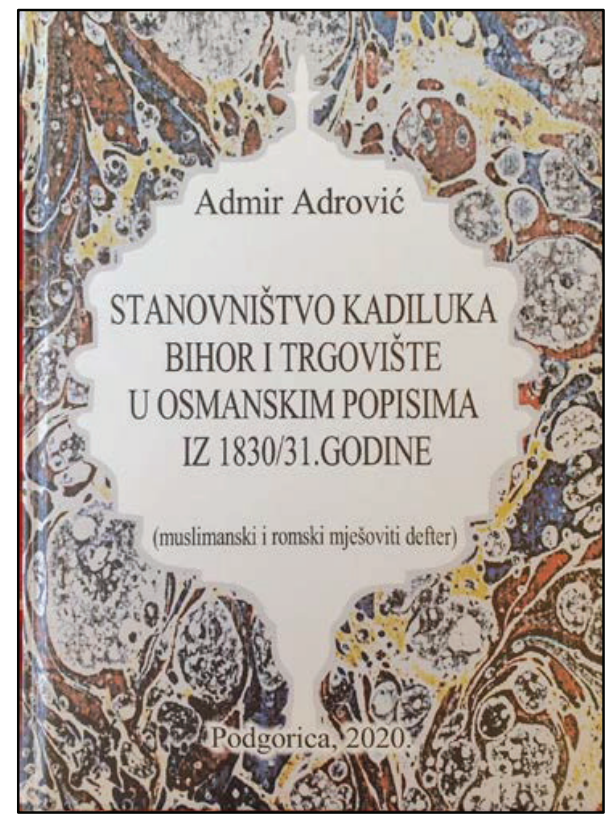
određena arhivska istraživanja, prije svega u Arhivu Predsjedništva Vlade, a zatim u još nekoliko manjih arhiva i biblioteka, gdje je uspio da pronađe dragocjenu arhivsku građu i starija istoriografska djela koja tretiraju zbivanja sa 
crnogorskih prostora. Pomenuta arhivska dokumenta su proizvod osmanske administracije i njenih činovnika, koji su, radeći u državnoj službi, bili u obavezi da revnosno bilježe sve ono što bi nastajalo kako na perifernim područjima Sultanata, tako i u onim krajevima koji su bili bliži osmanskoj prijestonici.

Istraživačka želja, a i interesovanje za demografske procese, naveli su Admira Adrovića da boraveći u Arhivu Predsjedništva Vlade u Istanbulu (BOA), dođe do vrlo dragocjenih otkrića. Naime, on je u toj instituciji otkrio pet deftera koji se odnose na teritorije kadiluka Bihor i Trgovište i to za hidžretsku 1248. godinu. To su tzv. nufus defteri, odnosno popisi stanovništva. Od tih pet deftera dva se odnose na muslimansko stanovništvo, dva na hrišćansko i jedan na romsko stanovništvo, koji je, uzgredno rečeno i mješoviti, jer su u njemu sadržani podaci za Rome muslimane i Rome hrišćane.

Nakon proučavanja prikupljenih prvorazrednih istorijskih dokumenata i istoriografskih djela koja su bila od pomoći za stvaranje što jasnije slike prošle stvarnosti na području kadiluka Bihor i Trgovište, Admir Adrović je pristupio transkripciji i prevođenju otkrivenih dokumenata, odnosno, na osnovu istorijskog izvora stvaranju rukopisa o stanovništvu koje je činilo, odnosno nastanjivalo pomenute kadiluke u vrijeme stvaranja ovih popisa. Uvažavajući metodološke postulate, Adrović je svoje djelo podijelio na Predgovor, Uvod i četiri veća poglavlja unutar kojih je situirao manje cjeline koje se mogu apostrofirati na osnovu onoga što je sadržano u nufus defterima koje je proučavao. Tako je u okviru prvog većeg poglavlja, koje ima naslov Nufus defteri kadiluka Bihor i Trgovište iz 1831. godine (13-30), autor izdvojio devet manjih cjelina preko kojih je dao najznačajnija određenja vezana za osmanske popise, koji svoje korijene imaju u predosmanskom periodu. Tako nas autor upoznaje sa terminom kadiluk, sa položajem i granicama kadiluka Bihor, granicama i položajem kadiluka Trgovište, sa tehničkim karakteristikama izučavanog deftera, sa starosnom i vjerskom strukturom stanovništva, sa fizičkim karakteristikama stanovništva, sa vojnosposobnim stanovništvom, sa antroponimima koji se susreću u defteru i sa popisanim Romima.

Drugo veće poglavlje ima naslov Popis muškaraca muslimana kadiluka Bihor koji pripada Prizrenskom sandžaku (30-114). U ovom dijelu autor nam daje prevod cjelokupnog dokumenta - popisa muškog stanovništva kadiluka Bihor, zasebno po svim naseljima (selima), ubicirajući i u napomenama objašnjavajući gdje se koje nalazi ili se nalazilo.

Osmanska administracija je pridavala veliki značaj preciznom evidentiranju stanovništva, jer joj je to bilo potrebno iz više razloga utvrđivanja prihoda, utvrđivanja katastarskih posjeda, raspodjele prihoda pripadnicima upravljačke strukture, utvrđivanja statusa stanovništva i njegovih obaveza, kao i zbog evidentiranja vojnih obveznika. Upravo u naznačenom kontekstu nastao je i prvi opšti popis muškog stanovništva u Osmanskom carstvu 1830/31. godine. Velikim dijelom popis je bio posljedica događaja iz 1826. godine kada je došlo do ukidanje janičarskog reda. U događajima koji su 
slijedili na području kadiluka Bihor i Trgovište, zbili su se mnogi događaji koji još uvijek čekaju da budu objašnjeni na naučan način. Ono što je izuzetno bitno pomenuti kada je u pitanju ukidanje janičara uopšte, pa time i u Bihoru i Trgovištu, jeste i pad Bektašija, derviškog reda čiji su pripadnici bili ideolozi janjičara. Povlačenje Bektašija u prostor tajnog djelovanja, bilo je praćeno brojnim ubistvima, zavjerama i mnogim drugim negativnostima koje su se ispoljile u svom brutalnom obliku. Izvor koji nam je ponudio Admir Adrović, uveliko može biti od koristi i za sagledavanje navedenih procesa, jer se preko datih popisa može pratiti trag svim muškim osobama koje su popisane tokom 1830/1831. godine, na način što bi se stanje upoređivalo sa popisom koji je, dvadeset godina kasnije, sproveo Omer Lutfi-paša.

$\mathrm{Za}$ osmanske popise bili su veoma zainteresovani na dvorovima $u$ Zapadnoj Evropi. Na osnovu podataka koje su dobijali iz tih popisa, zapadni istoričari su pisali različite vrste radova koji su se odnosili na Osmansku državu, koji su, prema ocjeni Admira Adrovića, bili etnografskog sadržaja i sa značajnim nedostacima.

Treće veće poglavlje Adrovićeve knjige odnosi se na Popis muškaraca muslimana u kadiluku Trgovište koji pripada Prizrenskom sandžaku (114-191). Kod ovog poglavlja autor je primijenio istovjetnu metodologiju kao kod prethodnog, što znači da je čitaocima ponuđen detaljan prevod deftera sa nazivima svih naselja i imenima stanovnika koji su u njima nastanjeni. Uz prevod, autor se pobrinuo da nas preko napomena informiše o svim detaljima koje je bilo nužno objasniti.

Poslednje posebno poglavlje odnosi se na Popis Roma - muslimana $i$ hrišćana kadiluka Bihor i Trgovište (191-194). Prevodom autentičnog dokumenta autor nam razotkriva prisustvo, takoreći, treće zajednice, koja je, uz muslimansku i hrišćansku, bivstvovala u Bihoru i Trgovištu.

U preostalom dijelu Adrovićeve knjige (199-347), dat je faksimil cjelokupnog deftera koji je on preveo sa osmanskog-turskog jezika. Pored ovoga knjiga sadrži i spisak korišćenih izvora i literature, kao i Index toponima, što čitaocima olakšava njeno korišćenje.

Uz sve navedeno, potrebno je reći da napor Admira Adrovića nije bio usmjeren samo na rasvjetljavanju demografskih prilika na lokalnom nivou, već, prije svega, da u opštim crtama ukaže na strateško i organizovano djelovanje državnih organa i njenog samog vrha, o čemu dovoljno govore i popisi stanovništva koji su sprovođeni u svim djelovima Osmanske carevine. Uvažavajući ranije primijenjen metodološke postupke u tumačenju istorijskih izvora slične sadržine, i Admir Adrović je u ovom radu dao najvažnija objašnjenja vezana za tehničke karakteristike pronađenog deftera, za starosnu i vjersku strukturu stanovništva i fizičke karakteristike stanovništva. Nisu izostale ni opšte napomene o Romima, kao etnikumu koji se uklapao u ukupni mozaik stanovništva kadiluka Bihor i Trgovište.

Objavljivanje ove značajne knjige, pomenimo i to, finansijski je podržao Fond za zaštitu i ostvarivanje manjinskih prava Crne Gore. 
Imajući sve navedeno u vidu, na samom kraju je potrebno odati priznanje Admiru Adroviću što je ukupnu crnogorsku bibliografiju, a posebno bibliografiju Bihora i rožajskog kraja, obogatio draguljem kakav je Popis stanovništva kadiluka Bihor i Trgovište 1830/1831. godine. Otkrivajući nam ovaj dragocjeni istorijski izvor iz dubine vjekova, Adrović nije dao samo nov istorijski izvor, već i podstrek za dalja izučavanja. Njegova istraživačka sonda realno ukazuje da postoje pravci u kojima je moguće vršiti svestranija proučavanja prostora Bihora i Trgovišta u raznim domenima.

Knjiga koju predstavljamo istovremeno može poslužiti i kao primjer plemenitih nastojanja autora da se od zaborava otrgnu segmenti društvenoistorijskog razvitka Bihora i Trgovišta. Zbog svega iskazanog, ova knjiga treba da zauzme ne samo odgovarajuće mjesto $u$ javnim, nego $i \mathrm{u}$ ličnim bibliotekama. 